\title{
New Cassane Diterpenoids from Caesalpinia sappan and Their Antiplasmodial Activity
}

\author{
Nai-Liang Zhu ${ }^{1,+}$ (D) , Zhong-Hao Sun ${ }^{1,+}{ }^{,}$Mei-Geng $\mathrm{Hu}^{1}{ }^{1}$, Tong-Yu Wu ${ }^{2}$, Jing-Quan Yuan ${ }^{3}$, \\ Hai-Feng $\mathrm{Wu}^{1}{ }^{1}$, Yu Tian ${ }^{1}$, Peng-Fei Li ${ }^{1}$, Jun-Shan Yang ${ }^{1}$, Guo-Xu Ma ${ }^{1, *}$ and Xu-Dong $\mathrm{Xu}^{1, *}$ \\ 1 Key Laboratory of Bioactive Substances and Resource Utilization of Chinese Herbal Medicine, \\ Ministry of Education, Beijing Key Laboratory of Innovative Drug Discovery of Traditional Chinese Medicine \\ (Natural Medicine) and Translational Medicine, Key Laboratory of Efficacy Evaluation of Chinese Medicine \\ against Glycolipid Metabolic Disorders, State Administration of Traditional Chinese Medicine, \\ Institute of Medicinal Plant Development, Peking Union Medical College and Chinese Academy \\ of Medical Sciences, Beijing 100193, China; zhu13liang@126.com (N.-L.Z.); sun_zhonghao@126.com (Z.-H.S.); \\ Humeigeng@126.com (M.-G.H.); hfwu@implad.ac.cn (H.-F.W.); ytian@implad.ac.cn (Y.T.); \\ lipengfei1121@126.com (P.-F.L.); jsyang@implad.ac.cn (J.-S.Y.) \\ 2 Center of Research and Development on Life Sciences and Environment Sciences, \\ Harbin University of Commerce, Harbin 150076, China; wty_lostheaven@163.com \\ 3 College of Chemistry and Materials Science, Guangxi Teachers Education University, Nanning 530001, \\ China; yjqgx@163.com \\ * Correspondence: gxma@implad.ac.cn (G.-X.M.); xdxu@implad.ac.cn (X.-D.X.); \\ Tel./Fax: +86-10-5783-3296 (X.-D.X) \\ + These authors contributed equally to this work.
}

Received: 24 August 2017; Accepted: 13 October 2017; Published: 17 October 2017

\begin{abstract}
One new cassane diterpene possessing an unusual $N$ bridge between C-19 and C-20 named caesalsappanin R (1), as well as another new diterpene caesalsappanin S (2), were isolated from the seeds of Caesalpinia sappan with methanol extract. Their structures were determined by spectroscopic analysis and examined alongside existing data from prior studies. Their biological activities were profiled by their antiplasmodial activity.
\end{abstract}

Keywords: Caesalpinia sappan; cassane diterpenes; $N$ bridge; antiplasmodial activity

\section{Introduction}

Caesalpinia sappan has been a part of traditional Chinese herbal medicine and is widely used in the treatment of dysmenorrheal, blood stagnation, and tetanus. Previous phytochemical investigations indicated that this genus contains an abundant source of cassane diterpenes with different structure types, and most of them showed in vitro or in vivo pharmacological impacts such as antiproliferative [1-3], antiplasmodial [4,5], antibacterial [6], antihelmintic, and antineoplastic activity [7]. As a continuation of our project towards new bioactive diterpenes discovery from the genus Caesalpinia [2,3,8], we examined the chemical constituents of $C$. sappan and obtained two new cassane diterpenes, designated caesalsappanin R (1) and caesalsappanin S (2) (Figure 1). Compound 1 is a rather unusual cassane diterpenoid lactone-type skeleton, consisting of an $N$ bridge between C-19 and C-20. In this paper, we detail the separation and structural determination of the novel agents and the examination of their antiplasmodial activity. 

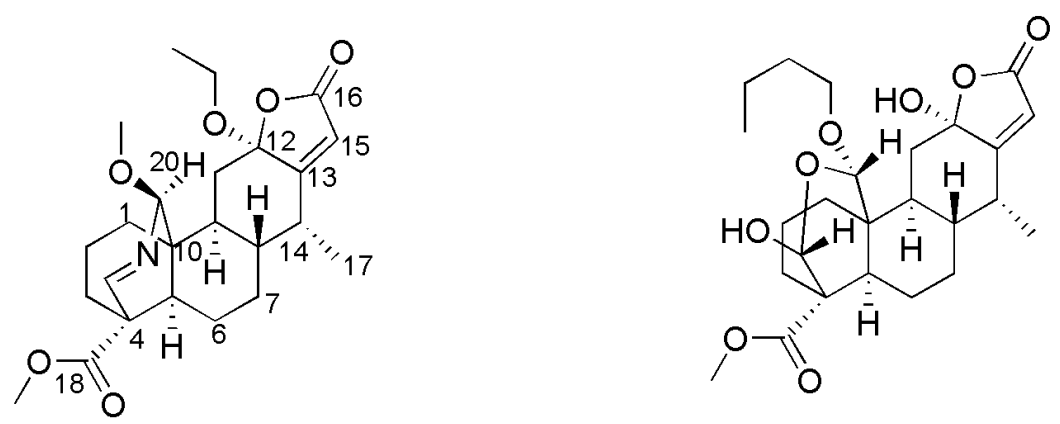

Figure 1. The structures of compounds 1-2.

\section{Results and Discussion}

\subsection{Purification of Compounds $\mathbf{1 - 2}$}

The seeds of $C$. sappan were extracted with $\mathrm{MeOH}$ three times. The two cassane-type diterpenoids were isolated and purified via silica gel chromatography, Sephadex LH-20 gel chromatography and semi-HPLC.

\subsection{Structure Elucidation of Compounds $\mathbf{1}-\mathbf{2}$}

Compound 1 was acquired as a white shapeless powder. The HRESIMS spectrum demonstrated a quasi-molecular ion at $m / z 454.2199$ (Calcd. for $\mathrm{C}_{24} \mathrm{H}_{33} \mathrm{NO}_{6} \mathrm{Na}, 454.2206$ ), which in connection with the NMR data, confirmed that the molecular formula was $\mathrm{C}_{24} \mathrm{H}_{33} \mathrm{NO}_{6}$. The IR and UV spectra revealed absorptions for an amidogen $\left(3190 \mathrm{~cm}^{-1}\right)$, a carbonyl $\left(1735 \mathrm{~cm}^{-1}\right)$, and an $\alpha, \beta$-unsaturated butenolide unit $\left(210 \mathrm{~nm} ; 1749 \mathrm{~cm}^{-1}\right)$ [2]. The ${ }^{1} \mathrm{H}$ and ${ }^{13} \mathrm{C}$ APT NMR spectra (Table 1) displayed the olefinic proton signal at $\delta_{\mathrm{H}} 5.86(\mathrm{H}-15, \mathrm{~s})$ and four downfield-shifted carbon signals at $\delta_{\mathrm{C}} 107.4(\mathrm{C}-12), 171.0(\mathrm{C}-13), 115.9(\mathrm{C}-15)$, and 179.9 (C-16), which also confirmed the presence of the $\alpha, \beta$-unsaturated butenolide ring. Additionally, the ${ }^{1} \mathrm{H}-\mathrm{NMR}$ spectrum exhibited signals for a methyl at $\delta_{\mathrm{H}} 1.14\left(\mathrm{~d}, J=7.2 \mathrm{~Hz}, \mathrm{H}_{3}-17\right)$, two methoxys at $\delta_{\mathrm{H}} 3.74\left(\mathrm{~s}, 18-\mathrm{OCH}_{3}\right)$ and $3.72\left(\mathrm{~s}, 20-\mathrm{OCH}_{3}\right)$, an ethoxy group at $\delta_{\mathrm{H}} 3.30,3.58\left(\mathrm{~m}, \mathrm{OCH}_{2} \mathrm{CH}_{3}\right)$ and 1.21 $\left(\mathrm{d}, J=7.2 \mathrm{~Hz}, \mathrm{OCH}_{2} \mathrm{CH}_{3}\right)$, a nitrogen oxymethylene proton at $\delta_{\mathrm{H}} 5.07(\mathrm{~d}, J=2.4 \mathrm{~Hz})$, and a nitrogen alkenyl at $\delta_{\mathrm{H}} 7.53$ (s). Except for the methoxy $\left(\delta_{\mathrm{C}} 52.2,57.1\right)$ and ethoxy $\left(\delta_{\mathrm{C}} 59.3,15.0\right)$ substituents, the ${ }^{13} \mathrm{C}$ APT NMR spectrum showed 20 carbons including one methyl $\left(\delta_{C} 12.2\right)$, six methylenes $\left(\delta_{C} 19.3,25.6,29.1\right.$, $30.2,33.1$, and 37.2), seven methines $\left(\delta_{C} 37.0,42.2,43.4,47.0,91.2,115.9\right.$, and 169.9$)$, and six quaternary carbons $\left(\delta_{C} 44.1,49.8,107.4,169.9,171.0\right.$, and 175.3). The HSQC spectrum displayed all of the proton signals assigned to the corresponding carbons through direct ${ }^{1} \mathrm{H}$ and ${ }^{13} \mathrm{C}$ correlations. The overall ${ }^{1} \mathrm{H}$ - and ${ }^{13} \mathrm{C}-\mathrm{NMR}$ spectroscopic data confirmed that $\mathbf{1}$ is an oxynitride diterpene possessing a fused butenolide unit $[9,10]$, and its entire structure was connected, as confirmed using HSQC, HMBC, and ${ }^{1} \mathrm{H}-{ }^{1} \mathrm{H}-\mathrm{COSY}$ spectra (Figure 2). The nitrogen oxymethylene proton at $\delta_{\mathrm{H}} 5.07(\mathrm{~d}, J=2.4 \mathrm{~Hz}, \mathrm{H}-20)$ showed long-range correlations with carbons at $\delta_{\mathrm{C}} 30.2$ (C-1), 49.8 (C-10), 162.6 (C-19), and $57.1\left(20-\mathrm{OCH}_{3}\right)$, which suggested that $\mathrm{C}-1, \mathrm{C}-10, \mathrm{C}-19$, and $-\mathrm{OCH}_{3}$ were connected through the nitrogen oxymethylene carbon C-20. The quaternary carbon $\mathrm{C}-4\left(\delta_{\mathrm{C}} 44.1\right)$ was connected to $\mathrm{C}-3\left(\delta_{\mathrm{C}} 33.1\right), \mathrm{C}-5\left(\delta_{\mathrm{C}} 47.0\right), \mathrm{C}-18\left(\delta_{\mathrm{C}} 175.3\right)$, and C-19 $\left(\delta_{\mathrm{C}} 162.6\right)$ due to the HMBC correlations of $\mathrm{H}-19, \mathrm{H}_{2}-3$, and $\mathrm{H}-5$ to $\mathrm{C}-4$ and $\mathrm{C}-18$. Moreover, the nitrogen bridge between $C-19$ and $C-20$ was confirmed by the downfield chemical shifts of $C-19\left(\delta_{C} 162.6\right)$ and $\mathrm{C}-20\left(\delta_{\mathrm{C}} 91.2\right)$ together with the HMBC correlations between $\mathrm{H}-19$ and $\mathrm{C}-20$. Finally, the $\alpha, \beta$-unsaturated butenolide moiety was connected to $\mathrm{C}-11$ and $\mathrm{C}-14$ based on the HMBC correlations from $\mathrm{H}_{2}-11$ to $\mathrm{C}-12$ $\left(\delta_{\mathrm{C}} 107.4\right)$ and $\mathrm{H}-14$ to $\mathrm{C}-13\left(\delta_{\mathrm{C}} 171.0\right)$. The proton $\mathrm{H}_{3}-17\left(\delta_{\mathrm{H}} 1.14, \mathrm{~d}, J=7.2 \mathrm{~Hz}\right)$ showed long-range correlations with carbons $\mathrm{C}-14\left(\delta_{\mathrm{C}} 37.0\right)$, which indicated that the methyl group of $\mathrm{C}-17$ was connected to $\mathrm{C}-14$. The methoxyl and ethoxyl groups were attached to $\mathrm{C}-18$ and $\mathrm{C}-12$, respectively, based on the HMBC correlations between $\delta_{\mathrm{H}} 3.74\left(\mathrm{~s},-\mathrm{OCH}_{3}\right)$ and $\delta_{\mathrm{C}} 175.3(\mathrm{C}-18), \delta_{\mathrm{H}} 3.30,3.58\left(\mathrm{~m}, \mathrm{OCH}_{2} \mathrm{CH}_{3}\right)$ and $\delta_{\mathrm{C}} 107.4$ (C-12). The NOESY experiment established the relative configuration of compound 1, the correlations of 
$\mathrm{H}-20\left(\delta_{\mathrm{H}} 5.07\right) / \mathrm{H}-1 \alpha\left(\delta_{\mathrm{H}} 1.69-1.72\right), \mathrm{H}_{3}-17\left(\delta_{\mathrm{H}} 1.14\right) / \mathrm{H}-9\left(\delta_{\mathrm{H}} 1.78\right), \mathrm{OCH}_{2} \mathrm{CH}_{3}-12\left(\delta_{\mathrm{H}} 3.30\right) / \mathrm{H}_{3}-17\left(\delta_{\mathrm{H}} 1.14\right)$ showed that the hydroxyl group was $\beta$-oriented at $\mathrm{C}-20$, and the methyl group at $\mathrm{C}-14$ and the ethoxy group at $\mathrm{C}-12$ were all $\alpha$-oriented. The same carbon skeleton with the trans/anti/trans system of three six-membered rings $\mathrm{A}, \mathrm{B}$, and $\mathrm{C}$, and the oriented proton at $\mathrm{C}-8$ was $\beta$-axial and the oriented protons at C-5/C-9 was $\alpha$-axial, which are well established on all cassane diterpenes isolated so far from the genus Caesalpinia $[3,8,11]$. Considering the biosynthetic relationship and comparing with the literature of cassane diterpenoids [12], the absolute configurations of the chiral carbons were determined to be $4 S, 5 R, 8 S$, 9S, 10S, 12S, 14R in $\mathbf{1}$ and are shown in Figure 2. Therefore, the structure of $\mathbf{1}$ was determined and it was named caesalsappanin R (Figure 1). Compound $\mathbf{1}$ is representative of a new cassane diterpenoid lactone-type skeleton with an $N$ bridge between C-19 and C-20.

Table 1. NMR spectral data of 1-2 ( $\mathrm{CDCl}_{3}, 600$ and $\left.150 \mathrm{MHz}\right)$.

\begin{tabular}{|c|c|c|c|c|c|}
\hline \multirow{2}{*}{ No. } & \multicolumn{2}{|c|}{1} & \multicolumn{2}{|r|}{2} & \multirow{2}{*}{$\begin{array}{c}\text { Caesalsappanin } \mathbf{H} \\
\delta_{\mathrm{C}} \text {, Type }\end{array}$} \\
\hline & $\delta_{\mathrm{C}}$, Type & $\delta_{\mathrm{H}}(J$ in $\mathrm{Hz})$ & $\delta_{\mathrm{C}}$, Type & $\delta_{\mathrm{H}}(J$ in $\mathrm{Hz})$ & \\
\hline 1 & $30.2 \mathrm{CH}_{2}$ & $\begin{array}{l}1.69-1.72(\mathrm{~m}) \\
2.17-2.21(\mathrm{~m})\end{array}$ & $37.7 \mathrm{CH}_{2}$ & $\begin{array}{l}1.28-1.30(\mathrm{~m}) \\
2.07-2.09(\mathrm{~m})\end{array}$ & $37.8 \mathrm{CH}_{2}$ \\
\hline 2 & $19.3 \mathrm{CH}_{2}$ & $\begin{array}{l}1.38-1.41(\mathrm{~m}) \\
2.59-2.63(\mathrm{~m})\end{array}$ & $20.6 \mathrm{CH}_{2}$ & $\begin{array}{l}1.58-1.60(\mathrm{~m}) \\
2.23-2.25(\mathrm{~m})\end{array}$ & $20.6 \mathrm{CH}_{2}$ \\
\hline 3 & $33.1 \mathrm{CH}_{2}$ & $\begin{array}{l}1.28-1.32(\mathrm{~m}) \\
1.89-1.93(\mathrm{~m})\end{array}$ & $28.5 \mathrm{CH}_{2}$ & $\begin{array}{l}1.82-1.83(\mathrm{~m}) \\
2.25-2.30(\mathrm{~m})\end{array}$ & $28.6 \mathrm{CH}_{2}$ \\
\hline 4 & $44.1 \mathrm{C}$ & & $50.3 \mathrm{C}$ & & $50.4 \mathrm{C}$ \\
\hline 5 & $47.0 \mathrm{CH}$ & $1.73(\mathrm{~m})$ & $47.2 \mathrm{CH}$ & $1.68-1.71(\mathrm{~m})$ & $47.2 \mathrm{CH}$ \\
\hline 6 & $25.6 \mathrm{CH}_{2}$ & $\begin{array}{l}1.18-1.20(\mathrm{~m}) \\
1.39-1.42(\mathrm{~m})\end{array}$ & $24.2 \mathrm{CH}_{2}$ & $\begin{array}{l}1.19-1.21(\mathrm{~m}) \\
2.00-2.02(\mathrm{~m})\end{array}$ & $24.2 \mathrm{CH}_{2}$ \\
\hline 7 & $29.1 \mathrm{CH}_{2}$ & $\begin{array}{l}1.69-1.72(\mathrm{~m}) \\
2.19-2.23(\mathrm{~m})\end{array}$ & $29.5 \mathrm{CH}_{2}$ & $\begin{array}{l}1.25-1.28(\mathrm{~m}) \\
1.60-1.62(\mathrm{~m})\end{array}$ & $29.5 \mathrm{CH}_{2}$ \\
\hline 8 & $43.4 \mathrm{CH}$ & $1.49(\mathrm{~m})$ & $41.5 \mathrm{CH}$ & $2.19-2.21(\mathrm{~m})$ & $41.1 \mathrm{CH}$ \\
\hline 9 & $42.2 \mathrm{CH}$ & $1.78(\mathrm{~m})$ & $41.3 \mathrm{CH}$ & $1.51-1.53(\mathrm{~m})$ & $41.3 \mathrm{CH}$ \\
\hline 10 & $49.8 \mathrm{C}$ & & $38.6 \mathrm{C}$ & & $38.7 \mathrm{C}$ \\
\hline 11 & $37.2 \mathrm{CH}_{2}$ & $\begin{array}{c}1.68-1.70(\mathrm{~m}) \\
2.75(\mathrm{dd}, 12.0,2.4)\end{array}$ & $38.0 \mathrm{CH}_{2}$ & $\begin{array}{l}1.36-1.38(\mathrm{~m}) \\
2.51-2.53(\mathrm{~m})\end{array}$ & $38.1 \mathrm{CH}_{2}$ \\
\hline 12 & $107.4 \mathrm{C}$ & & $105.5 \mathrm{C}$ & & $105.9 \mathrm{C}$ \\
\hline 13 & $171.0 \mathrm{C}$ & & $173.4 \mathrm{C}$ & & $173.7 \mathrm{C}$ \\
\hline 14 & $37.0 \mathrm{CH}$ & $2.99(\mathrm{qd}, 7.2,2.4)$ & $37.1 \mathrm{CH}$ & $2.91(\mathrm{qd}, 7.2,2.4)$ & $37.1 \mathrm{CH}$ \\
\hline 15 & $115.9 \mathrm{CH}$ & $5.86(\mathrm{~s})$ & $113.5 \mathrm{CH}$ & $5.69(\mathrm{~s})$ & $113.8 \mathrm{CH}$ \\
\hline 16 & $169.9 \mathrm{C}$ & & $170.7 \mathrm{C}$ & & $170.7 \mathrm{C}$ \\
\hline 17 & $12.2 \mathrm{CH}_{3}$ & $1.14(\mathrm{~d}, 7.2)$ & $12.0 \mathrm{CH}_{3}$ & $1.13(\mathrm{~d}, 7.2)$ & $12.1 \mathrm{CH}_{3}$ \\
\hline 18 & $175.3 \mathrm{C}$ & & $175.6 \mathrm{C}$ & & $175.5 \mathrm{C}$ \\
\hline 19 & $162.6 \mathrm{CH}$ & $7.53, \mathrm{~s}$ & $90.1 \mathrm{CH}$ & $5.60(\mathrm{~s})$ & $90.1 \mathrm{CH}$ \\
\hline 20 & $91.2 \mathrm{CH}$ & $5.07(\mathrm{~d}, 2.4)$ & $104.2 \mathrm{CH}$ & $4.49(\mathrm{~s})$ & $105.4 \mathrm{CH}$ \\
\hline & 59.3, $\mathrm{CH}_{2}$ & $\begin{array}{l}3.30(\mathrm{~m}) \\
3.58(\mathrm{~m})\end{array}$ & & & \\
\hline $\mathrm{OCH}_{2} \mathrm{CH}_{3}-12$ & $15.0, \mathrm{CH}_{3}$ & $1.21(t, 7.2)$ & & & \\
\hline $\mathrm{OCH}_{3}-18$ & 52.2 & $3.74(\mathrm{~s})$ & 52.0 & $3.71(\mathrm{~s})$ & 51.7 \\
\hline $\mathrm{OCH}_{3}-20$ & 57.1 & $3.72(\mathrm{~s})$ & & & 55.7 \\
\hline $\mathrm{OCH}_{2} \mathrm{CH}_{2} \mathrm{CH}_{2} \mathrm{CH}_{3}-20$ & & & 67.8 & $\begin{array}{l}3.22(\mathrm{ddd}, 9.6,6.0,3.0) \\
3.80 \text { (ddd, 9.6, 6.0, 3.0) }\end{array}$ & \\
\hline $\mathrm{OCH}_{2} \mathrm{CH}_{2} \mathrm{CH}_{2} \mathrm{CH}_{3}-20$ & & & 31.9 & $\begin{array}{l}1.32(\mathrm{~m}) \\
1.47(\mathrm{~m})\end{array}$ & \\
\hline $\mathrm{OCH}_{2} \mathrm{CH}_{2} \mathrm{CH}_{2} \mathrm{CH}_{3}-20$ & & & 20.0 & $\begin{array}{l}1.28(\mathrm{~m}) \\
1.43(\mathrm{~m})\end{array}$ & \\
\hline $\mathrm{OCH}_{2} \mathrm{CH}_{2} \mathrm{CH}_{2} \mathrm{CH}_{3}-20$ & & & 13.7 & $1.87(t, 7.2)$ & \\
\hline
\end{tabular}




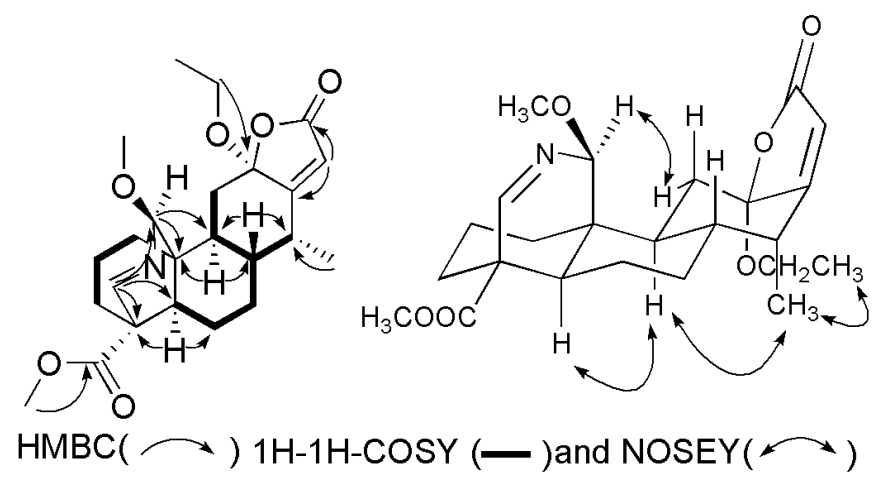

Figure 2. Key 2D NMR correlations of compound $\mathbf{1 .}$

Compound 2 was separated as a white shapeless powder, $[\alpha]_{\mathrm{D}}^{20}-47.3(c=0.1, \mathrm{MeOH})$. Its molecular formula was determined to be $\mathrm{C}_{25} \mathrm{H}_{36} \mathrm{O}_{8}$ by HRESIMS (observed $m / z 487.2332\left[\mathrm{M}+\mathrm{Na}^{+}\right.$). The ${ }^{1} \mathrm{H}$ - and ${ }^{13} \mathrm{C}-\mathrm{NMR}$ data displayed a cassane diterpene skeleton with an oxygen bridge between C-19 and C-20, which was very similar to the reported compound caesalsappanin H [3]. In fact, the only difference between them was that the methoxy group at C-20 in caesalsappanin $\mathrm{H}$ was replaced with a butoxy group in 2 . The ${ }^{1} \mathrm{H}$ - and ${ }^{13} \mathrm{C}-\mathrm{NMR}$ spectra displayed the signals at $\delta_{\mathrm{H}} 3.22,3.80(2 \mathrm{H}$, ddd, $\left.J=9.6,6.0,3.0 \mathrm{~Hz}, \mathrm{CH}_{2}\right), 1.32,1.47\left(2 \mathrm{H}, \mathrm{m}, \mathrm{CH}_{2}\right), 1.28,1.43\left(2 \mathrm{H}, \mathrm{m}, \mathrm{CH}_{2}\right), 1.87\left(3 \mathrm{H}, \mathrm{t}, J=7.2 \mathrm{~Hz}, \mathrm{CH}_{3}\right)$ and $\delta_{\mathrm{C}} 67.8\left(\mathrm{CH}_{2}\right), 31.9\left(\mathrm{CH}_{2}\right), 20.0\left(\mathrm{CH}_{2}\right), 13.7\left(\mathrm{CH}_{3}\right)$, which suggested the presence of a butoxy group. Also, the HMBC correlations from $\mathrm{CH}_{2}\left(\delta_{\mathrm{H}} 3.22,3.80\right)$ to $\mathrm{C}-20\left(\delta_{\mathrm{C}} 104.2\right)$ supported the position of the butoxy group at C-20. Taken along with ${ }^{1} \mathrm{H}-{ }^{1} \mathrm{H}$ COSY, HSQC, HMBC, and NOE spectra, the structure of compound 2 was determined and it was named caesalsappanin $S$ (Figure 1).

\subsection{In Vitro Antiplasmodial and Larvicidal Activities of Compounds 1-2}

The two compounds were tested against the chloroquine-resistant strain $\mathrm{K} 1$ of P. falciparum (Table 2). Compound $\mathbf{1}$ exhibited relatively good antiplasmodial activity in vitro with $\mathrm{IC}_{50}$ values of $3.6 \mu \mathrm{M}$, compared with chloroquine. On the other hand, compound 2 showed only weak activity against the chloroquine-resistant K1 strain of P. falciparum. It appears that the presence of the $N$ bridge in cassane-type diterpenoids may play an important role in enhancing activity against the chloroquine-resistant K1 strain of P. falciparum in vitro. Furthermore the toxic activity of compounds 1 and $\mathbf{2}$ against mosquito larvae was evaluated. Both compounds displayed only low activity.

Table 2. In vitro antiplasmodial and Larvicidal activities of compounds 1-2.

\begin{tabular}{ccc}
\hline Compounds & IC $_{\mathbf{5 0}}(\boldsymbol{\mu M})^{\mathbf{a}}$ & LC $_{\mathbf{5 0}}(\boldsymbol{\mu M})^{\mathbf{b}}$ \\
\hline $\mathbf{1}$ & $3.60 \pm 1.2$ & $60.2 \pm 2.3$ \\
$\mathbf{2}$ & $25.1 \pm 1.3$ & $262.0 \pm 8.7$ \\
Chloroquine $^{\mathrm{c}}$ & $0.19 \pm 0.05$ & $38.6 \pm 2.1$
\end{tabular}

${ }^{\mathrm{a}} \mathrm{IC}_{50}=$ inhibitory concentration $50 \%{ }^{\mathrm{b}} \mathrm{LC}_{50}=$ lethal concentration $50 \%$. Values are means $\pm \mathrm{SD}$ of triplicate experiments. ${ }^{\mathrm{c}}$ Positive control substance.

\section{Materials and Methods}

\subsection{General Experimental Procedures}

Optical rotation data were measured with a Perkin-Elmer 341 digital polarimeter (PerkinElmer, Norwalk, CT, USA). UV and IR data spectra were recorded on Shimadzu UV2550 and FTIR-8400S spectrometers (Shimadzu, Kyoto, Japan). NMR spectra were obtained using a Bruker AV III 600 NMR spectrometer with chemical shift values presented as $\delta$ values having TMS (Tetramethylsilane) as the internal standard. HRESIMS was performed using an LTQ-Orbitrap XL spectrometer (Thermo Fisher 
Scientific, Boston, MA, USA). Column-chromatography (CC) was performed using silica gel (100-200 and 300-400 mesh, Qingdao Marine Chemical Plant, Qingdao, China), Sephadex LH-20 (Pharmacia, Uppsala, Sweden). Precoated silica gel $\mathrm{GF}_{254}$ plates (Zhi Fu Huang Wu Pilot Plant of Silica Gel Development, Yantai, China) were used for TLC. All solvent used was of analytical grade (Beijing Chemical Plant, Beijing, China).

\subsection{Plant Material}

The seeds of $C$. sappan were collected from Nanning, Guangxi Province, People's Republic of China, in April 2013, and identified by Professor Jing Quan Yuan of the Department of Pharmaceutical Chemistry, Guangxi Botanical Garden of Medicinal Plants. A voucher specimen (NO. 13418) was deposited at the Guangxi Botanical Garden of Medical Plants.

\subsection{Isolation and Purification of Compounds $\mathbf{1}-\mathbf{2}$}

The air-dried seeds of $C$. sappan $(5.0 \mathrm{~kg})$ were extracted with $\mathrm{MeOH}(3 \times 40 \mathrm{~L}, 3 \mathrm{~h}$ each) at room temperature. Removal of the $\mathrm{MeOH}$ under reduced pressure yielded a $\mathrm{MeOH}$-soluble extract $(1267 \mathrm{~g})$. The residue was suspended to $\mathrm{H}_{2} \mathrm{O}(3 \mathrm{~L})$ and partitioned with petroleum ether $(3 \times 3 \mathrm{~L}), \mathrm{CH}_{2} \mathrm{Cl}_{2}$ $(3 \times 3 \mathrm{~L})$, EtOAc $(3 \times 3 \mathrm{~L})$, and $\mathrm{n}-\mathrm{BuOH}(3 \times 3 \mathrm{~L})$, successively. The EtOAc fraction $(164 \mathrm{~g})$ was subjected to CC (column-chromatography) over silica gel (100-200 mesh, $15 \times 60 \mathrm{~cm}$ ) eluting with a stepwise gradient of $\mathrm{CH}_{2} \mathrm{Cl}_{2}-\mathrm{MeOH}$ (from 1:0 to 0:1, 100:0, 90:1, 70:1, 50:1, 30:1, 20:1, 10:1, 5:1, 2:1, 1:1, $0: 1, v / v)$ to afford fractions A-G. Fraction $\mathrm{E}(3.1 \mathrm{~g})$ was subjected to chromatographed repeatedly over silica gel CC eluting with $\mathrm{CH}_{2} \mathrm{Cl}_{2}-\mathrm{MeOH}(50: 0,40: 1,30: 1,20: 1,10: 1, v / v)$ to obtained sub-fractions Fractions E1-E5. Fraction E3 was separated using silica gel CC eluting with $\mathrm{CH}_{2} \mathrm{Cl}_{2}-\mathrm{MeOH}(40: 1,30: 1$, $0: 100, v / v)$ to obtained sub-fractions I-III. Sub-fraction II was purified by semi-HPLC of $\mathrm{MeOH}-\mathrm{H}_{2} \mathrm{O}$ $(55: 45, v / v)$ as the mobile phase to yield compound $1\left(6.3 \mathrm{mg}, 0.000146 \%, t_{\mathrm{R}}=28.4 \mathrm{~min}\right)$. Fraction E2 was separated using silica gel CC eluting with $\mathrm{CH}_{2} \mathrm{Cl}_{2}-\mathrm{MeOH}(50: 1, v / v)$, yielding compound 2 (8.6 mg, $0.000172 \%)$.

\subsection{Characterization of Compounds 1-2}

Caesalsappanin R (1), White powder $(\mathrm{MeOH}) ;[\alpha]_{\mathrm{D}}^{20}-24.2(c=0.05, \mathrm{MeOH}) ; \mathrm{UV}(\mathrm{MeOH}) \lambda_{\max }(\log \varepsilon)$ 210 (3.86) nm; IR (film) $v_{\max } 3190,1745,1735 \mathrm{~cm}^{-1} ;{ }^{1} \mathrm{H}$ - and ${ }^{13} \mathrm{C}-\mathrm{NMR}$ data $\left(\mathrm{CDCl}_{3}\right)$, see (Table 1); HR-ESI-MS $m / z 454.2199$ [M + Na] ${ }^{+}$. (Calcd. for. $454.2206 \mathrm{C}_{24} \mathrm{H}_{33} \mathrm{NO}_{6} \mathrm{Na}$ ).

Caesalsappanin S (2), White powder (MeOH); $[\alpha]_{\mathrm{D}}^{20}-47.3(c=0.1, \mathrm{MeOH}) ; \mathrm{UV}(\mathrm{MeOH}) \lambda_{\max }(\log \varepsilon) 213$ (3.94) $\mathrm{nm}$; IR (film) $v_{\max } 3450,1730 \mathrm{~cm}^{-1} ;{ }^{1} \mathrm{H}$ - and ${ }^{13} \mathrm{C}-\mathrm{NMR}$ data $\left(\mathrm{CDCl}_{3}\right)$, see (Table 1); HR-ESI-MS $m / z$ 487.2332 [M + Na] $]^{+}$(Calcd. for. $487.2308 \mathrm{C}_{24} \mathrm{H}_{34} \mathrm{O}_{8} \mathrm{Na}$ ).

\subsection{Antiplasmodial Assays of Compounds 1-2}

Antiplasmodial activity in vitro was determined by means of the microculture radioisotope technique based on the method described by Desjardins [13]. The parasite P. falciparum (K1, multidrug-resistant strain) was cultured continuously according to the method of Trager and Jensen [14]. Three preparations were used for each experiment. The determination of $\mathrm{IC}_{50}$ values against the erythrocytic stages of P. falciparum was carried out in duplicate using the [3H]-hypoxanthine incorporation assay [15]. Laboratory colonies of mosquito larvae/pupae (Culex quinquefasciatus Say, Diptera, Culicidae) were used for the larvicidal/pupicidal activity. Twenty-five numbers of first to fourth instars larvae and puape were introduce into $500 \mathrm{~mL}$ glass beaker containing $249 \mathrm{~mL}$ of de-chlorinated water and $1 \mathrm{~mL}$ of desired concentrations of ethanolic leaf extract were added. Larval food was given for the test larvae. At each tested concentration two to five trials were made and each trial consisted of five replicates. The control was setup by mixing $1 \mathrm{~mL}$ of acetone with $249 \mathrm{~mL}$ of dechlorinated water. The larvae and pupae were exposed to dechlorinated water without acetone served as control. The control mortalities were corrected by using Abbott's formula [16,17]. 
The $\mathrm{LC}_{50}$ were calculated from toxicity data by using probit analysis [18]. Chloroquine was included as a standard for comparison. Data are presented as means $\pm \mathrm{SEM}$. Statistical analyses were done by means of the Student's $t$-test. A $P$ value of less than 0.05 was considered a significant difference.

\section{Conclusions}

In conclusion, two new cassane-type diterpenoids ( $\mathbf{1}$ and $\mathbf{2}$ ) were isolated and characterized by spectrometric analysis (1 and 2D NMR, HRESIMS). Compound 1 exhibited active antiplasmodial activity in vitro with $\mathrm{IC}_{50}$ at $3.60 \mu \mathrm{M}$. In addition, the compounds that we had reported also showed antiplasmodial activities; caesalsappanins A, G, H, and I displayed antiplasmodial activities with $\mathrm{IC}_{50}$ values of $7.4,0.78,0.52$, and $2.5 \mu \mathrm{M}$, respectively [3]. Therefore, we believe that this plant is an important source for the diverse structure of cassane-type diterpenoids and should be further investigated for the antiplasmodial activity.

Acknowledgments: The work was financially supported by the Technological Large Platform for Comprehensive Research and Development of New Drugs in the Twelfth Five-Year "Significant New Drugs Created" Science and Technology Major Projects (No. 2012ZX09301-002-001-026), the National Science and Technology Support Program (No. 2012BA127B06), the Innovation Capacity Building in Guangxi Science and Technology Agency (No. 10100027-3), the National Natural Sciences Foundation of China (No. 81502945), and the PUMC Youth Fund (No. 3332015141), Key Medical Research Projects in Guangxi (2011029) and Research projects of Shenzhen Science and Technology Program (GCZX 2015050411225563).

Author Contributions: Guo-Xu Ma, Xu-Dong Xu, and Jun-Shan Yang conceived and designed the experiments; Nai-Liang Zhu, Zhong-Hao Sun, Mei-Geng Hu, Tong-Yu Wu, Jing-Quan Yuan, and Hai-Feng Wu performed the experiments; Yu Tian and Peng-Fei Li analyzed the data; Nai-Liang Zhu and Guo-Xu Ma wrote the paper.

Conflicts of Interest: There is no conflict of interest associated with the authors of this paper.

\section{References}

1. Consolacion, Y.; Ragasa, J.G.H.; John, A.R. New Furanoid Diterpenes from Caesalpinia pulcherrima. J. Nat. Prod. 2002, 65, 1107-1110.

2. Ma, G.X.; Yuan, J.Q.; Wu, H.F.; Cao, L.; Zhang, X.P.; Xu, L.J.; Wei, H.; Wu, L.Z.; Zheng, Q.X.; Li, L.Y.; et al. Caesalpins A-H, Bioactive Cassane-Type Diterpenes from the Seeds of Caesalpinia minax. J. Nat. Prod. 2013, 76, 1025-1031. [CrossRef] [PubMed]

3. Ma, G.X.; Wu, H.F.; Chen, D.L.; Zhu, N.L.; Zhu, Y.D.; Li, P.F.; Sun, Z.H.; Yang, J.S.; Xu, X.D. Antimalarial and Antiproliferative Cassane Diterpenes of Caesalpinia sappan. J. Nat. Prod. 2015, 78, 2364-2371. [CrossRef] [PubMed]

4. Yodsaoue, O.; Cheenpracha, S.; Karalai, C.; Ponglimanont, C.; Chantrapromma, S.; Fun, H.K.; Kanjana, O.A. Phanginin A-K, diterpenoids from seeds of Caesalpinia sappan Linn. Phytochemistry 2008, 69, 1242-1249. [CrossRef] [PubMed]

5. Pudhom, K.; Sommit, D.; Suwankitti, N.; Petsom, A. Cassane Furano-diterpenoids from the Seed Kernels of Caesalpinia bonduc from Thailand. J. Nat. Prod. 2007, 70, 1542-1544. [CrossRef] [PubMed]

6. Dickson, R.A.; Houghton, P.J.; Hylands, P.J. Antibacterial and antioxidant cassanediterpenoids from Caesalpinia benthamiana. Phytochemistry 2007, 68, 1436-1441. [CrossRef] [PubMed]

7. Cheenpracha, S.; Karalai, C.; Ponglimanont, C.; Chantrapromma, K.; Laphookhieo, S. Cassane-type diterpenes from the seeds of Caesalpinia crista. Helv. Chim. Acta 2006, 89, 1062-1066. [CrossRef]

8. Xu, X.D.; Yang, J.Q.; Zhou, X.Y.; Li, W.P.; Zhu, N.L.; Wu, H.F.; Li, P.F.; Sun, Z.H.; Yang, J.S.; Ma, G.X. Cassane diterpenes with oxygen bridge from the seeds of Caesalpinia sappan. Fitoterapia 2016, 112, 205-210. [CrossRef] [PubMed]

9. Wang, W.X.; Xiong, J.; Tang, Y.; Zhu, J.J.; Li, M.; Zhao, Y.; Yang, G.X.; Xia, G.; Hu, J.F. Rearranged abietane diterpenoids from the roots of Clerodendrum trichotomum and their cytotoxicities against human tumor cells. Phytochemistry 2013, 89, 89-95. [CrossRef] [PubMed]

10. Rayanil, K.; Limpanawisut, S.; Tuntiwachwuttikul, P. Entpimarane and enttrachylobane diterpenoids from Mitrephora alba and their cytotoxicity against three human cancer cell lines. Phytochemistry 2013, 89, 125-130. [CrossRef] [PubMed] 
11. Nguyen, H.X.; Nguyen, N.T.; Dang, P.H.; Ho, P.T.; Nguyen, M.T.T.; Can, M.V.; Dibwe, D.F.; Ueda, J.Y.; Awale, S. Cassane ditrpenes from the seed kernels of Caesalpinia sappan. Phytochemistry 2016, 122, 286-293. [CrossRef] [PubMed]

12. Zhang, J.Y.; Abdel-Mageed, W.M.; Liu, M.M. Caesanines A-D, New Cassane Diterpenes with Unprecedented N Bridge from Caesalpinia sappan. Org. Lett. 2013, 15, 4726-4729. [CrossRef] [PubMed]

13. Desjardins, R.E.; Canfield, C.J.; Haynes, J.D.; Chulay, J.D. Quantitative assessment of antimalarial activity in vitro by a semiautomated microdilution technique. Antimicrob. Agents Chemother. 1979, 16, 710-718. [CrossRef] [PubMed]

14. Trager, W.; Jensen, J.B. Human Malaria in Continuous Culture. Science 1976, 193, 673-675. [CrossRef] [PubMed]

15. Vennerstrom, J.L.; Arbe-Barnes, S.; Brun, R.; Charman, S.A.; Chiu, F.C.K.; Chollet, J.; Dong, Y.; Dorn, A.; Hunziker, D.; Matile, H.; et al. Identification of an antimalarial synthetic trioxolane drug development candidate. Nature 2004, 430, 900-904. [CrossRef] [PubMed]

16. Kovendan, K.; Murugan, K.; Panneerselvam, C.; Aarthi, N.; Mahesh, P.K.; Subramaniam, J.; Amerasan, D.; Kalimuthu, K.; Vincent, S. Antimalarial activity of Carica papaya (Family: Caricaceae) leaf extract against Plasmodium falciparum. Asian Pac. J. Trop. Dis. 2012, 2, S306-S311. [CrossRef]

17. Abbott, W.S. A method of computing the effectiveness of insecticides. J. Econ. Entomol. 1925, $265-267$. [CrossRef]

18. Finney, D.J. Probit Analysis; Cambridge University: London, UK, 1971; pp. 68-78.

Sample Availability: Samples of the compounds 1-2 are available from the authors.

(C) 2017 by the authors. Licensee MDPI, Basel, Switzerland. This article is an open access article distributed under the terms and conditions of the Creative Commons Attribution (CC BY) license (http:// creativecommons.org/licenses/by/4.0/). 